\title{
Hairy on the Inside: From Cannibals to Paedophiles
}

\author{
Carolyn Daniel
}

Those slavering jaws; the lolling tongue; the rime of saliva on the grizzled chops - of all the teeming perils of the night and the forest, ghosts, hobgoblins, ogres that grill babies upon gridirons, witches that fatten their captives in cages for cannibal tables, the wolf is worst, for he cannot listen to reason ... Fear and flee the wolf; for worst of all, the wolf may be more than he seems. (Carter 1979, p.283)

0 tories about monsters who threaten to consume, whether they are wolves, witches, sharks or aliens continue to be the mainstay of much grotesque-horror fiction aimed at both children and adults. Monsters such as these act outside cultural and social prohibitions and represent the antithesis of civilised humanity. Those who eat badly threaten the coherence of the social order, reveal the precariousness of humankind's place at the top of the food chain and remind us of the corporeality of our bodies - that our flesh can be classified as meat just as readily as that of any other animal. Monstrous eaters also remind us of the moral dilemma that eating evokes; even the most everyday and benign act of eating involves aggression and the sacrifice of another living organism. As Mikhail Bakhtin puts it in Rabelais and His World: 'the body ... swallows, devours, rends the world apart, is enriched and grows at the world's expense' (Bakhtin 1968, p.281).

As well as being physically vital, eating is an act that is fundamentally significant in terms of individual psychology. It also carries enormous cultural and social meaning. The infant's first feeding relationship, for example, is of crucial importance in the formation of individual subjectivity and cultural stereotypes. Initially, the infant is as one with the mother/breast; there is no distinction between self and other, eater and eaten, inside and outside. Maggie Kilgour points out that this situation contains dangerous elements of cannibalism: 'In this primary stage of identification the eater is the eaten - or at least imagines it is' (Kilgour 1990, p.12, original emphasis). The child soon discovers, however, that what it considered to be part of itself is in fact separate or outside its self. Thus, the familiar becomes strange (p.12). Kilgour emphasises the way structural differences are produced and perpetuated by this situation and believes that the inside/outside opposition is the foundation of all binary oppositions. She shows how the model for the inside/outside opposition is 'based on bodily experience and the sense that what is "inside" one's own body is a coherent structure that can be defined against what lies “outside" of it' (Kilgour 1990, p.4). Indeed, Freud in 'Negation' suggests that the inside/outside opposition is the basis for all future decisions:

Expressed in the language of the oldest, that is, of the oral, instinctual impulses, the judgement is: 'I should like to eat this', or 'I should like to spit it out'; and, put more generally: 'I should like to take this into myself and to keep that out'. That is to say: 'It shall be inside me'or 'it shall be outside me'... the original pleasure-ego wants to introject into itself everything that is good and to eject from itself everything that is bad. What is bad, what is alien to the ego and what is external are, to begin with, identical.

(Freud 1925, p.668)

As Kilgour comments, this crude schema defines everything inside as good while everything outside is bad. This hypothesis is presented as universally significant on an individual level. In the West, however, this system of values extends from the individual level to motivate many more sophisticated notions of social and corporate values, so that outsiders or 'others' are defined as bad, evil or transgressive and are a source of fear (Kilgour 1990, p.4). In Western society and culture at least, and universally on an individual level, control can be maintained if the other is somehow subsumed or incorporated so that there is no category of alien outsideness left to threaten the inner stability' (p.5). Melanie Klein (1981) theorised that the infant's fear of being devoured by the mother is a reaction to its own desire to assimilate or possess that which is external to the self. In a similar way Kilgour argues individuals/cultures/societies project the desire for assimilation onto the other, 'a tactic that has been shown to be at work in psychic defenses, misogyny, racism and imperialism' (Kilgour 1990, p.5).

The dualism inside/outside can arguably be cited as the basis of the nostalgia for (but also fear of) a state of unity or oneness found in many myths and fables. Kilgour cites the paradise of Genesis and Milton, Coleridge's dream of 'Self, that no alien knows' ('Religious Musings'), and 
Ahab's Moby-Dick as fictions that are

bound to a nostalgia for a state of total incorporation that underlies many of the major trends of Western thought: idealism, scientific rationalism, traditional psychoanalysis, as well as imperialism, and theories in general that try to construct a transcendental system or imagine a single body that could contain all meaning. (Kilgour 1990, p.5)

The dualism inside/outside, therefore, derived from the infant's first feeding relationship, arguably has universal significance and it provides the basis of many aspects of Western cultural belief systems. In the West there is a ubiquitous and explicit desire in individuals, cultures, social and corporate organizations to create order, dispel disorder and quell transgression by eliminating the Other. Kilgour remarks that recent studies of imperialism and colonial discourses have shown how a society's desire to appropriate other cultures can be disguised through the projection of that impulse onto the Other (Kilgour 1990, p.5), that is, by labelling the Other 'cannibal'. The appropriation of other cultures by the West is achieved by a process of assimilation, inculcation or through consumption. Elspeth Probyn argues that Western anthropology and Western interests in general have had something of a preoccupation with the notion of cannibalism, which, she says, 'reveals much about the colonial imagination' (2000, p. 70). 'Eating the Other', according to bell hooks, is a metaphor for imperial violence (cited by Probyn 2000, p. 70).

Even though, as Klein (1981) argues, cannibalism is a phantasy universally experienced by infants, for Western culture it is a taboo so great that it is deemed to be an inhuman act performed by those outside civilised society. Indeed, Western culture uses the cannibal, as the epitome of monstrousness, to define humanity. Cannibalism is a trope that can be interpreted as a metaphor and in this paper I examine historical metaphors of cannibalism, used in stories for children, in an attempt to trace the changing cultural fears that evoke them. Stories about monsters with abominable appetites have multiple functions: they may reflect a desire for familial or social integrity; they may reveal cultural unease about social hierarchies; they may warn of material dangers and therapeutically rehearse the fears invoked by such threats, wearing them out through repeti- tion; they may explore issues regarding intergenerational and familial rivalries, confirming the individual's place in society; they may reveal society's concerns about the need to discipline the appetites and behaviour of children; and they may reflect social anxieties about enemy Others, the identity of whom changes over time.

Cannibalism as a practice continues to be part of human culture. ${ }^{1}$ Margaret Visser reports that it has been historically practised in 'Africa south of the Sahara, in Oceania, America North, Central and South, in northern Europe, and in the ancient Mediterranean region' (Visser 1993, p.7). In Western anthropological terms aggressive cannibalism, or eating the enemy, is known as exophagy. William B. Seabrook apparently witnessed this practice during his travels to the French Ivory Coast in the 1930s. The Guere tribe ritually ate the flesh of men from conquered tribes killed during battle (Seabrook 1993, p.536-540). Visser reveals that endo-cannibals, who ritually consume dead family members, have been described as 'cemeteries for their dead' and that they may believe, for instance, that the 'life essence' of the dead relative must be ingested to ensure the good health and continuing fertility of their tribe (Visser 1993, p.11-12). Susanne Skubal refers to endophagy as 'affectionate' cannibalism and suggests it was 'a response to separation anxiety, a way of perpetuating presence and undoing loss' (Skubal 2002, p.106). Kilgour suggests cannibalism might also be seen as a form of nostalgia, recalling 'a deeper, if ambivalent desire to recover a time before the emergence of modern individuated subjectivity' (Kilgour 1998, p.247).

Interestingly Philip Pullman includes both forms of cannibalism in His Dark Materials trilogy. In the first book, Northern Lights, Iorek Byrnison defeats the king of the armoured bears:

[He] sliced open the dead king 's unprotected chest, peeling the fur back to expose the narrow white and red ribs like timbers of an upturned boat. Into the ribcage Iorek reached, and he plucked out Iofur's heart, red and steaming, and ate it there in front of Iofur's subjects.

Then there was acclamation, pandemonium, a crush of bears surging forward to pay homage to Iofur's conqueror. 
Iorek Byrnison's voice rose above the clamour.

\section{'Bears! Who is your king?'}

And the cry came back, in a roar like that of all the shingle in the world in an ocean-battering storm:

\section{'Iorek Byrnison!'}

(1995, p.354)

Iorek's exophagous act is symbolic and may be interpreted as a consolidation of power. He consumes the heart (the metaphorical repository of courage and the soul) of the king and replaces him in the social order. He becomes king. This marries with Skubal's report: in some societies it was apparently common for the victorious cannibal to take the name of his victim, thus completing the full process of incorporation and identification, a process which, she suggests, 'call[s] to mind the communicant who takes the name of Christ-ian'(2002, p.105). In Pullman's third book, The Amber Spyglass, Iorek engages in endophagy.

\begin{abstract}
[B] ecause the Texan aeronaut was one of the very few humans Iorek had ever esteemed, he accepted the man's last gift to him. With deft movements of his claws, he ripped aside the dead man's clothes, opened the body with one slash, and began to feast on the flesh and blood of his old friend ... something ... possessed his heart, something bright and hard and unshakeable: vengeance ... The good man's flesh and bone would both nourish him and keep him restless until blood was spilled enough to still his heart.
\end{abstract}

(2001, pp.44-45)

Again the heart is used as a metaphor for the emotions and Iorek's affection for the man and knowledge of his bravery and undeserved death stir his desire for revenge. The eater is transformed by both these acts of eating. In 'Totem and Taboo' Freud suggested that by incorporating parts of a person's body through the act of eating, one at the same time acquires the qualities possessed by him (1913, pp.496499). In many respects, therefore, the psychological aspects of cannibalism have been seen as reflecting a yearning for wholeness, oneness or integrity, notions also apparent in sexual desire, communion rituals and 'back to the womb' impulses (Sceats 2000, p.5). Cannibalism is thus an act that not only provides the eater with physical sustenance but also has inherent metaphoric symbolism. It is interesting to note that Pullman's description of Iorek's cannibalism is not framed as particularly monstrous. Indeed, it is implied that his actions are appropriate, honourable and dignified. This is an unusual stance given that, in general, cannibalism is condemned by Western society, is accepted as part of the practices of an inferior culture, and ascribed to an Other who is uncivilised and primitive.

\section{Colonial Discourses}

The trope of the 'native' as cannibal with an inordinate capacity to consume human flesh as an especially delectable food is, according to Gananath Obeyesekeve, a white cultural construction and central to the construction of the non-European as Other (1998, p.63). Clare Bradford has shown how the trope was used in early Australian literature to produce and reinforce the discourse of Aboriginal as Other. As she remarks, cannibalism is the "ultimate in colonial projections of fear of the Other, constituting the most extreme manifestation of savagery and the absolute proof of white superiority'(2001,p.38). In Richard Rowe's adventure novel The Boy in the Bush (1869), for example, Aborigines are generally treated as savages, cannibals and, Bradford adds, 'convenient moving targets during episodes of warfare' (2001, p. 6). Rowe's narrative contains the following passage: '[I]n a fight with another tribe, several of his captors were slain. The corpses were brought back and roasted, peeled like potatoes, and eaten by their own comrades' $(1869$, p.205). Bradford comments that the phrase 'eaten by their own comrades' implies 'a special kind of decadence' and it suggests that eating one's enemies might perhaps be preferable (2001, p.38). Rowe's description of the cooked flesh being 'peeled like potatoes' introduces a notion of culinary familiarity and ordinariness to the proceedings. The attention to detail and the particulars of the cooking method described reads almost like a recipe. The everyday quality of the simile used, juxtaposed with the fact that human flesh is being consumed, is intended to evoke shudders of disgust in the reader.

An exophagous episode occurs in R. M. Ballantyne's The Coral Island (1858). Ralph, who narrates the story, describes a battle between two groups of 'savages'. The 
victorious tribe kindle a fire and bring forward one of their bound enemies:

Next moment one of the savages raised his club, and fractured the wretched creature's skull. He must have died instantly; and strange though it may seem, I confess to a feeling of relief when the deed was done, because I now knew that the poor savage could not be burned alive. Scarcely had his limbs ceased to quiver when the monsters cut slices of flesh from his body, and, after roasting them slightly over the fire, devoured them.

(p.134)

The 'civilised' white narrator is distanced from the horrific act committed by the monstrous savages because he makes his sensibilities and sympathies clear. It is interesting, though macabre, to note the contrast between the cooking methods used in Ballantyne's and Rowe's texts. In Rowe's story the description of the eaters peeling the roasted corpse before eating produces notions of a peculiarly restrained and considered ritual. In Ballantyne's, however, disgust and abjection are evoked by the image of slices of flesh being cut from the victim's body when he had 'scarcely' stopped moving. Significantly the flesh of the victim is only roasted 'slightly' suggesting rawness; Ballantyne thus makes use of the raw/cooked dualism, which Claude Lévi-Strauss (1966) theorised equates structurally to the nature/culture, primitive/civilised oppositions. In both narratives cannibalism symbolises the brutish, immoral, uncivilised state in which the 'natives' exist. This, of course, serves to highlight the civilised, moral superiority of the white Westerners and to justify racist discourses. With reference to Australian literature, Bradford emphasises that 'colonial and Aboriginalist discourses survive in contemporary texts that promote the central tenet of these discourses - the inherent superiority of Western culture'. The doctrine is, however naturalised through narrative strategies that normalise and often make it difficult to identify (2001, p.47).

Kilgour succinctly remarks that, while the act of cannibalism has traditionally been used to establish difference and construct racial boundaries dividing the civilised from the savage, it also paradoxically dissolves the differences between eater and eaten, desire and dread, love and aggres- sion, human-as-subject and meat-as-object. In this way it unsettles discrete categories and confuses opposites and this is why it ultimately evokes horror (1998, p.240).

\section{Parental Cannibalism in Fairy Tales}

As I remarked earlier, acts of monstrous eating are usually confined to the page or screen of the gothic horror narrative, but they also, somewhat ironically, occur in fairy tales traditionally deemed to be appropriate bedtime reading for young children. Jack Zipes argues that fairy tales featuring wolves, witches and ogres had a more literal meaning in their original form and he suggests that as such they performed a didactic role with a more material and less of a psychological function. Citing the work of Marianne Rumpf, he writes:

one of the most common European warning tales ... in the Middle Ages involved hostile forces threatening children who were without protection. Either an ogre, ogress, man-eater, wild person, werewolf, or wolf was portrayed as attacking a child in the forest or home. The social function of the story was to show how dangerous it could be for children to talk to strangers in the woods or to let strangers enter the house.

(Zipes 1993, pp.18-19)

Rumpf argues that werewolves in particular were often the subjects of such cautionary tales and that in France, during the sixteenth and seventeenth centuries

there was a virtual epidemic of trials against men accused of being werewolves ... similar to the trials against women as witches ...[they were] generally charged with having devoured children ... There were literally thousands if not hundreds of thousands of such cases.

(Zipes 1993, p.19)

Oral tales of werewolves, including early versions of the story of 'Little Red Riding Hood', Rumpf argues, existed in the nineteenth and twentieth centuries in areas where werewolf trials were most common in the fifteenth, sixteenth and seventeenth centuries (Zipes 1993,p.20). Zipes confirms the original storytellers of Perrault's and the Grimms' literary tales were influenced first and foremost by the material conditions of their existence. 'Little children 
were attacked and killed by animals and grown-ups in the woods and fields. Hunger often drove people to commit atrocious acts' (1993, p.23).

George Devereaux, citing 'Multatuli (1868)', pseudonym of novelist Edward Douwes Dekker, reports that during medieval famines and 'even during the great postrevolutionary famine in Russia' the 'actual eating of one's children or the marketing of their flesh' occurred. He concludes that 'the eating of children in times of food shortage is far from rare' (Devereaux 1966, pp.127-9). During a later period Jonathan Swift notoriously satirised British policy towards the famine in Ireland in 'A Modest Proposal' (1729), when he suggested with impassive rationalism that the starving Irish 'raise their children as delicacies to be consumed at table' (Warner 2000, p.7; Visser 1993, p.65). ${ }^{2}$ Hunger, as Zipes has noted, can drive people to think about and even commit atrocities.

In pre-modern Europe, famine 'plays a prominent role in fairy tales [which] comes as no surprise when we consider the chronic food shortages and periods of scarcity that afflicted those who shaped these stories'(Tatar 1992, p.192). While cannibalism did not appear to be particularly commonplace in Europe, child abandonment apparently was. According to Maria Tatar, it "took place with astonishing regularity in pre-modern Europe, where rates of child abandonment in urban areas probably ranged from 15 to 20 per cent of registered births'(1992, p.xxi). In the light of such statistics the fate of Hansel and Gretel (being abandoned in the woods by parents because the family was starving) was a real possibility for urban children. Warner has also suggested that tales of bogeymen and ogresses who steal babies and children away — a probable euphemism for child abandonment — were used as 'a justification for neglecting babies with birth defects or other problems. A changeling could be discreetly made to disappear, as an evil gift of the fairies, or even of the devil' (2000, p.28). Thus fairy tales not only warned against but also echoed the awful truth of child abandonment (and consumption) in times of famine and were also a supernatural explanation for the disappearance of unwanted children.

'Hansel and Gretel' is perhaps the best known tale that starts with a time of famine, but so do 'Tom Thumb', 'The Knapsack, the Hat, and the Horn', 'God's Food', 'The
Sweet Porridge' and 'The Children of Famine'. ${ }^{3}$ This last tale, 'The Children of Famine', exemplifies the plight of families unable to feed their children. When the mother in this story runs out of food she becomes 'unhinged and desperate' and tells her two daughters that she will have to kill them so that she will have something to eat. The children desperately attempt to pacify their mother by begging for crusts of bread, but this only gives them a temporary reprieve. Finally and inconclusively they offer to 'lie down and sleep... until the Judgement Day arrives' and their mother departs 'and nobody knows where she went' (Zipes 1992/1987, pp.704-5). Tracy Willard notes that cannibalism, when practised by women in fairy tales, is almost always mother/child oriented whereby the motherfigure is 'presented in a negative light as a type of monster or witch' $(2002 \mathrm{~b}, \mathrm{p} .3)$. Tatar reports that, according to historical evidence, cases of real-life maternal cannibalism were not unknown but were invariably linked to mental derangement caused by malnutrition. Documented cases of maternal cannibalism are extremely rare, but when recorded in medical or legal documents, they always occur in connection with a baby, not a grown child (1992, p.193).

Warner differentiates between the meanings of metaphors of maternal and paternal cannibalism in classical myth. Significantly, she associates maternal cannibalism with motives that are 'merely practical [and] callous', being an act that 'nullifies the meaning of maternity, rather than attempting to supplant the mother's role' as, she argues, does paternal cannibalism. She believes that paternal cannibalism represented an 'inverted birthing: biological ownership through incorporation' (2000,p.56). Paternal cannibalism is exemplified in the tale of 'The Juniper Tree' (in Zipes, 1992/1987, p.171), a tale that, according to Tatar, has 'long been recognised as one of the most powerful of all fairy tales' (1992, p.212). In this story, which purports to record events which took place 'some two thousand years ago' (Zipes 1992/1987, p.171), a boy child is born to a woman who had prayed day and night for a child. However she dies shortly after giving birth. As she had requested, her husband buries her under the juniper tree. He later marries a woman who has a daughter of her own whom she loves, but she hates her step-son. There follows 'what is probably the most savage scene of revenge staged in any fairy tale' (Tatar 1992, p.212). The stepmother encourages the 
boy to look for an apple in a chest that has 'a large heavy lid with a big, sharp iron lock’ (Zipes 1992/1987, p.172). Prompted by the devil she kills the boy by slamming the lid of the chest 'so hard that his head flew off and fell among the apples' (p.173). Then she cuts up the boy's body and makes it into a stew that she serves to his father when he returns home. He eats with relish,

'Oh, wife, the food tastes great! Give me some more!'The more he ate, the more he wanted. 'Give me some more, 'he said. 'I'm not going to share this with you. Somehow I feel as if it were all mine'. (Zipes 1992/1987, pp.173-4)

This story is resolved by the death of the stepmother and the restoration of the boy to life through the magical, maternal influence of the juniper tree. The boy takes his father and stepsister by the hand 'and all three were very happy. Then they went into the house, sat down at the table, and ate' (p.179). It is significant that it is the boy who takes control of his family and takes them into the house. The meal they eat together signals a normalisation of family relations and an end to the calamitous events of the past (Tatar 1992, p.226).

Warner points out that in this tale, as in the myth of Kronos, the Greek myth of divine origin, incorporation into the father does not mean absolute death. 'Paternity, in this fairy tale ... can bring forth the whole child again' (2000, p.63). Significant to Warner's understanding of this tale is the sequence of the act of consumption and metaphorical rebirth that serve to consolidate paternal power. Biology is negated; the threatening physical presence of the step/ mother is eradicated, although she continues to affect the course of the story through the juniper tree. Warner sees this fairy tale and the Greek myth as
a lesson in the resignation of the passage of time, the overtaking of age by youth, and the necessar- ily stepped character of the genealogical ladder through life ... Terrible tales of aberration and abomination constantly invoke, by inversion and trespass, an ideal of normal practice and expected categories. (2000, pp.65-67)

Fairy stories that feature paternal cannibalism thus seem to have significantly different emphases to those where a mother-figure threatens to consume a child. In many stories a monstrous mother or wicked witch figure symbolises the bad breast of infantile phantasy theorised by Klein (1981). Defeating the witch arguably signifies separation from the mother, a necessary stage in psychic development. Significantly, although gullible and apparently hungry, the father figure in 'The Juniper Tree' is not a malevolent figure. Indeed, it is the mother figure who is split into good and evil, who is duplicitous and must be overcome. Being consumed by the father does not mean psychic obliteration or death as it does when the mother devours. Instead 'The Juniper Tree' explores issues such as personal identity, procreation, intergenerational, familial and patriarchal power relations and authority and confirms the male child's privileged role in society.

\section{Therapeutic Outcomes}

Contemporary stories of eaters with cannibalistic appetites frequently contain lurid detail intended to sicken and horrify the reader/viewer. It is pertinent to consider why such gut-churning detail, such as features in Thomas Harris's Hannibal Lecter series, for example, appears to be so compelling. Oral folktales, too, were originally far more gruesome than the sanitised versions generally in current circulation. Their censorship was a deliberate manoeuvre designed to comply with Christian ethics (Tatar 1992; Zipes 1993). Tatar cites Italo Calvino, who was so shocked by the cannibalistic elements of the oral version of 'Little Red Riding Hood', that he re-wrote it. In Calvino's source the wolf kills the heroine's grand/mother, uses her tendons to latch the door, chops up her flesh to make a meat pie and pours her blood into a wine bottle. The heroine, with obvious pleasure, consumes both the meat pie and the blood (Tatar 1992, p.209). Yvonne Verdier argues that by consuming the flesh and blood of her grandmother the young girl symbolically replaces her; the grandmother's death in this folk tale thus signifies the continuity and reinvigoration of custom that was important for the preservation of society (cited by Zipes 1993, p.24). Thus this cannibalistic consumption is symbolic in the same way as that described in Pullman's narrative when Iorek Byrnison becomes king. The folk tale thus explores notions of intergenerational and familial relations in terms of the female child's role in society. Tatar also points out the interesting way in which 
this version of the tale effaces the line dividing the agent from the victim of oral aggression (1992, pp.209-210). In this way the tale, in its original version (gruesome details intact), may prove to be therapeutic. The listener may identify with the active role of the heroine and is not forced into identification with the girl as victim.

In many children's playground games the line between agent and victim is similarly effaced. In Philip Pullman's Northern Lights, mentioned above, children are being systematically 'stolen' and supposedly eaten by a group of 'invisible kidnappers' who are referred to as the 'Gobblers'. The threat of being 'took' by the Gobblers is used by parents to encourage their children to behave, 'Don't stay out late, or the Gobblers'll get you!' The children playing on the street invent a game called 'kids and Gobblers' based on the game of Hide and Seek. 'You hide and I'1l find you and slice you open, right' (Pullman 1995, p.46). Similarly, one of the playground games I best remember from my childhood in Wales in the late '60s was 'What's the time Mr Wolf?' Once the 'wolf' had caught his 'dinner', the victim became the new wolf and the game continued. Turner, Factor and Lowenstein have a whole chapter of similar games in their collection, Cinderella Dressed in Yella, and date the 'Mr Wolf' game to the period ' $c$. 1935-1970' in Victoria (1978, p.59). Scherf maintains that these types of games and their repetitions help children to 'master anxiety and the shudders of horror, and finally to wear them out' (cited by Tatar 1992, p.210). Importantly, of course, the players get the chance to act out the role of both wolf/gobbler and victim.

On a similar note, but referring to games adults play with young children, anthropologist Gregory Bateson devised a theory of play that proposed that 'testing the limits of safety and entertaining the terror of murder and torment help to confirm the child's sense of security with the parent or caregiver'. One of his girl child patients told him, 'When we play monsters, and mummy catches me, she never kills me, she only tickles me' (cited by Warner 2000, p.144). Warner believes, however, that these games and fairy tales such as 'Little Red Riding Hood' are primarily didactic:

This kind of terror-play can comfort and thrill at the same time only when there is deep, familiar trust between the players - one of the latent messages of lullabies, nursery rhymes and fairy tales is not to trust the stranger, especially the big stranger of the male kind, but to remain at home, at rest in the familiar small world close to hand.

Games of thrills and spills, stirring phantoms of bogeymen, snatchers, and watchers, then become part of the process of learning the norms of social languages, and of differentiating oneself within them.

(pp.144-5)

Thus Warner recognises the duality of these narratives and games: they 'comfort and thrill'. She also confirms what Zipes and Rumpf suggest: games and stories that evoke 'terror' are cautionary tales, warn of material dangers and didactically reinforce the notion of the child's rightful place in the social hierarchy. They also, through repetition, therapeutically 'wear out' the immediacy and intensity of the fear and horror they produce.

In her insightful chapter on lullabies, 'Sing Now Mother...What Me Shall Befall', Warner asserts that lullabies have a similar therapeutic function. While the principal function of lullabies was, by implication, to lull the baby to sleep, the songs also calm the caregiver and make their daily struggle bearable. Significantly they also "carry female voices and concerns across time on their words and in their tunes'. But lullabies not only induce comfort and sleep, they also often include blessings for the well-being of the child and attempt to ward off danger by anticipating and invoking figures of death and punishment. The repetitive nature of the lullaby is 'a form of incantation. A lullaby is weak domestic magic, alert to its own inadequacy' (Warner 2000, pp.192-4). Traditional myths and fairy tales and even, arguably, contemporary horror genre narratives also have this sort of restorative effect, tempering real fears by facing what generates them in fictional form. In a similar way Warner argues that the extremes of participatory performances such as rock concerts, orgiastic jubilation such as experienced at raves, and spectator entertainments such as horror films can be viewed as rites of passage, testing endurance. They 'defin[e] ... the living, impervious, sovereign self' as well as providing the ecstatic 'high' of surviving (p.125). The adrenalin 'high' Warner refers to may account for the addictive quality of these activities 
and narratives.

In this section I have outlined the possible therapeutic outcomes of listening to, reading or viewing horror narratives or playing games that suggest oral aggression. In some cases, as in the Mr Wolf game, the line between agent and victim is effaced, identification with the role of victim is not forced upon the players as it is in some narratives; games played with adult parents/caregivers may allow the child to test the limits of safety and security; the repetition of tales or lullabies featuring oral aggression may wear out the intensity of the fear they produce; such narratives may act as a form of incantation, warding off danger by invoking it; endurance may be tested and fears tempered by facing them; the repetition of these narratives may serve to harden or de-sensitise the listener/viewer to their horror.

Narratives in the horror genre have always inspired both dread and delight although the monster's physiognomy has tended to change over time, reflecting social unease about enemy 'Others'. Warner argues that throughout history the characters invoked in warning stories are frequently drawn on enemy Others in their own time and place. Gypsies, Jews, Turks, [and] blacks have all been used to scare the young into obedience' (2000, p.161). In the world Pullman creates the Gobblers serve the same purpose. The following British 'lullaby' features Napoleon Bonaparte as the enemy 'Other', described as ' giant', 'black' and cannibalistic.

Giant Bonaparte

Baby, baby, naughty baby,

Hush, you squalling thing, I say!

Peace this moment, peace, or maybe

Bonaparte will pass this way.

Baby, baby, he's a giant, Tall and black as Rouen steeple,

And he breakfasts, dines, rely on't, Every day on naughty people.

Baby, baby, if he hears you, As he gallops past the house,

Limb from limb at once he 'll tear you, Just as pussy tears a mouse.
And he'll beat you, beat you, beat you And he'll beat you all to pap, And he'll eat you, eat you, eat you, Every morsel, snap, snap, snap! (Wignell 1990, p.1; Tatar 1993, p.32)

The threat of Bonaparte as cannibalistic monster is used to caution the infant and has a clearly didactic function as well as voicing fears about the enemy whose identity is historically relevant. Tatar points out that similar melodies have been used to lull French and Spanish babies, with Wellington and Bismarck, or El Coco, the Bull, or the Moorish Queen standing in for Bonaparte (1993, p.32). The oral threat remains constant.

\section{Little Red Riding Hood's Journey}

As my aim in this paper is to examine the way cultural fears have historically evoked changing emphases in metaphors of cannibalism it is both productive and interesting to trace the evolution of one particular tale and, given its continuing popularity and relevance 'Little Red Riding Hood' seems a good choice. As I have already hinted, older oral versions of the story appear in retrospect to be particularly bloodthirsty, but Tatar points out that adult audiences had relied for centuries on the telling of such tales 'to shorten the hours devoted to repetitive household chores or harvesting tasks'. Is it any wonder, Tatar asks, 'that they demanded fast-paced adventure stories filled with bawdy episodes, violent scenes, and scatological humour?' (1993, p.37).

In The Trials and Tribulations of Little Red Riding Hood Jack Zipes includes an early oral variant of the tale, 'The Story of Grandmother' (1993, pp.21-23), which was supposedly the source material for Perrault's (1695) tale. The little girl in this story has no red hood (Perrault introduced this element in his later version). She is asked by her mother to carry a 'hot loaf and bottle of milk' to her granny. 'At the crossway she met bzou, the werewolf', who asks her whether she is going to take the 'path of needles or the path of pins?' (p.21). On hearing that the little girl is to take the path of needles, the werewolf takes the path of pins to the grandmother's house. Meanwhile the little girl gathers needles. The werewolf kills the grandmother ' and put some of her meat in the cupboard and a bottle of her blood on the shelf'. When the little girl arrives the wolf tells her to 
put the bread and milk in the cupboard and to help herself to the meat and 'the bottle of wine'. 'After she had eaten, there was a little cat which said: "Phooey! ... A slut is she who eats the flesh and drinks the blood of her granny"'. The werewolf instructs the little girl to undress 'And come and lie down beside me' (p.21). As she removes each item of clothing she asks 'Where should I put my apron [and, in turn, bodice, dress, petticoat, long stockings]?' and the wolf responds, 'throw [them] into the fire my child, you won't be needing [them] anymore' (pp.21-22). When the little girl has 'laid herself down in the bed' the familiar dialogue begins: 'Oh granny, how hairy you are!' 'The better to keep myself warm, my child'. The wolf makes excuses for possessing various masculine characteristics until the little girl finally exclaims ' $O$ h granny, what a big mouth you have!' and receives the reply 'The better to eat you with, my child!' At this the little girl says 'Oh granny, I have to go badly. Let me go outside'. The wolf tries to persuade her to 'Do it in the bed, my child!' but she protests, 'Oh no, granny, I want to go outside' (p.22). The werewolf attaches a rope to the little girl's foot and lets her go outside where she promptly ties the end of the rope to a plum tree and escapes. The werewolf becomes impatient calling out 'Are you making a load out there? Are you making a load?' but there is no reply. Although he follows her he arrives 'at her house just at the moment she entered' (p.23).

In the first written version of the tale, by Perrault, 'Petit Chaperon Rouge'_-'Little Red Riding Hood'(Zipes 1993, pp.91-93), the protagonist must take biscuits and butter to her grandmother who is ill. In Perrault's story Little Red Riding Hood makes a number of fatal errors: firstly she stops to talk to the wolf, then she gives him directions to grandmother's house, and finally she amuses herself 'by gathering nuts, chasing butterflies, and making nosegays while the wolf zooms off, taking a shortcut to the house' (Tatar 1993, p.37). The wolf eats the grandmother and puts on her clothes and when the little girl enters the house he tells her to leave her clothes and come to bed. The 'celebrated dialogue' (Dundes 1988, p.21) sequence follows but the child's urgent request 'to go' and her subsequent escape are missing from this story. Instead the wicked wolf eats her (Zipes 1993, p.93). Tatar suggests that while oral 'folk' versions of the story were more concerned with 'entertaining an audience by rehearsing a sequence of racy episodes and sensational events', later versions such as Perrault's and later the Grimms' were more about 'presenting lessons' (1992, p.37). There are several major changes in Perrault's version that alter not only the outcome but also, importantly, the characterisation of the little girl. Significantly the little girl's overt cannibalism and the 'ritualistic striptease' (Dundes 1988, p.21) are left out.

Willard points out that in its oral variant 'this is one of the few (if not the only) ... European tale (featuring female cannibalism) in which cannibalism is perpetrated by a child and by a 'good' character'. She argues that this act, although committed in ignorance on the part of the child and effected by trickery, makes the little girl powerful and therefore potentially dangerous. Perrault's omission of this element therefore disempowers the character (Willard 2002a, p.5). Zipes also argues that Perrault's tale disempowers the girl child but his reasoning differs: he explains that in the oral folk-tale version/s the little girl is shrewd and self-reliant whereas in Perrault's version she is 'totally helpless' and neither clever nor assertive enough to outwit the wolf (1993, p.25). With regards to the endophagy in the oral tale, as I mentioned above, Zipes sees this as a ritualistic act symbolising the young girl's replacement of her grandmother. The oral version is thus a tale celebrating the girl's coming of age (1993, p.24). In this respect the folk version of this tale reflects the sentiments present in 'The Juniper Tree' and in the Greek myth of Kronos mentioned earlier, confirming the natural progress of time and youth overtaking age.

Zipes argues that Perrault's 'upper-class version' of 'Little Red Riding Hood' disempowers the protagonist but that this attitude reflected contemporaneous ways of thinking about the child. Referring to Philippe Aries' Centuries of Childhood, Zipes explains that during the period of the late seventeenth-century 'an independent children's literature and culture were being developed to civilise children according to stringent codes of class behaviour' (1993, p.25). Whereas the 'peasant' girl of the oral version had been 'forthright, brave and shrewd', Perrault's Red Riding Hood is 'pretty, spoiled, gullible and helpless' (p.26). Perrault's version talks about 'vanity, power, and seduction, and it introduced a new child, the helpless 
girl, who subconsciously contributed to her own rape' (p.27, original emphasis). The threat presented by the were/wolf remains the same - consumption/rape. The change occurs in the girl's ability to counter the threat. She is not the worldly-wise, resourceful and powerful girl in the folk tale, but instead becomes a disobedient child requiring punishment. The story becomes a didactic tool, implicitly warning of young girls' propensities for transgressive behaviour as much as, if not more than, the wolf's desire to take advantage of what such girls ostensibly offer. This changing emphasis reflects, primarily, a shift in attitudes towards children, as Zipes suggests and Tatar confirms when she explains that textual indicators in the tale "consistently construct a sybaritic heroine rather than a rapacious wolf (1993, p.38).

The Grimms' collection of fairy stories was originally published in two volumes (1812 and 1815). Within a few decades they became known throughout Europe and beyond (McGlathery 1988, p.vii). The Grimm brothers' version of 'Little Red Riding Hood', which they called 'Rotkappchen' - 'Little Red Cap' (1812), further sanitised the tale. In this story there was a 'sweet little maiden. Whoever laid eyes upon her could not help but love her' (Zipes 1992/1987, p.101). She is sent by her mother to visit her sick grandmother with cake and wine. In contrast to the oral folk tale where no prohibitions are put upon the child, so that the heroine cannot be perceived to be disobedient or transgressive, the Grimms' story includes an extensive list of dos and don'ts. She is specifically told to get an early start on her journey before it becomes hot and to "be nice and good and don't stray from the path, otherwise you'll fall and break the glass, and your grandmother will get nothing. And when you enter her room, don't forget to say good morning, and don't go peeping in corners' (pp.101-102). Although Little Red Cap promises to 'do just as you say', when she meets the wolf in the forest she stops to talk to him. Because she 'did not know what a wicked sort of an animal he was' she was not afraid of him (p.102). Even though illustrations tend to show her carrying a basket (though the text does not mention it), the wolf asks Little Red Cap what she is carrying under her apron. This question, Willard suggests, alludes to the food she is carrying but is also sexually suggestive (2002a, p.7). When the wolf asks her where her grandmother lives she gives him explicit directions: 'Another quarter of an hour from here in the forest. Her house is under the three big oak trees. You can tell it by the hazel bushes' (Zipes, 1992/1987, p.103). When the wolf suggests that she pick some of the beautiful flowers that are growing all around her and listen to the birds' lovely singing instead of 'march[ing] along as if [she] were going straight to school', Little Red Cap concurs and runs off the path 'plung[ing] into the woods to look for flowers. And each time she plucked one, she thought she saw another even prettier flower and ran after it, going deeper and deeper into the forest'. Indeed, she forgot all about her grandmother until 'she had [collected] as many [flowers] as she could carry' (p.103). Much emphasis is therefore placed on the seductive suggestions of the wolf and the hedonistic active pleasures Little Red Cap opts for rather than obeying her mother's instructions, which advocate passivity.

In this version of the story the wolf gobbles up granny, puts on her clothes and nightcap, gets into her bed and draws the curtains. When Little Red Cap enters, the traditional dialogue begins. "No sooner did the wolf say ["The better to eat you with"] than he jumped out of bed and gobbled up poor Little Red Cap' (pp.103-104). Significantly, 'After the wolf had satisfied his desires, he lay down in the bed again, fell asleep, and began to snore very loudly' (p.104). The wolf's desires are implicitly carnal as well as explicitly gastronomic; his after-dinner nap is akin to post-coital slumber.

A passing huntsman rescues both females when he cuts open the wolf with a pair of scissors and Little Red Cap and her grandmother emerge, a process of paternal re-birth similar to that in the Kronos myth. Male agency is thus twice valorised in this Grimm version. The wolf is killed by having his open belly filled with stones, again a clear connection to the myth in which Kronos swallows his children to prevent being usurped by them and is tricked into eating a rock instead of his youngest child. The moral to the story is summed up in Little Red Cap's last thought addressed to herself: 'Never again will you stray from the path by yourself and go into the forest when your mother has forbidden it' (p.104). However, the Grimms hammer home the moral of the story by illustrating how well Little Red Cap has learnt her lesson. They repeat the early events of the tale, but this time the girl is good, doesn't stray from the 
path and proceeds straight to Grandmother's. Grandmother astutely guesses the wolf's plan but outwits him, placing a trough of sausage-smelling water on the hearth. On the roof 'Grayhead', enticed by the smell, leans down until he falls into the trough and drowns (pp.104-105).

An examination of the sanitised variants of 'Little Red Riding Hood' in relation to the structural oppositions inside/outside, good/evil discussed at the beginning of this paper is revealing. The little girl is cautioned by her mother to stay upon the path, to remain 'inside' the boundaries of the social order and not to stray into the forest, representing 'outside', disorder and chaos. The wolf is also coded as 'outside', he is deviant, a transgressor, outside social control. Red Riding Hood strays 'outside' and is assimilated by the wolf assuming a state of unity with him. Notably being eaten by the wolf does not result in digestion. Instead she becomes as one with the wolf and his wild evil nature. As was the case when she consumes her granny's flesh in the oral folk tale, and when Iorek Byrnison devours the heart of the king in Pullman's story, Red Riding Hood becomes part of the wolf and, significantly, he becomes part of her. The wolf is an enemy 'Other', rapacious, wild and inhuman, threatening the cohesiveness of the social order, but so is the little girl according to this discourse. Her transgressive act (leaving the 'inside' path) places her on the 'outside'. She becomes the wolf.

It is significant that the versions of 'Little Red Riding Hood' that continue to be most widely circulated stick to versions of Perrault's or the Grimms' adaptations, continuing 'the stereotyping of little girls as innocent creatures who must be protected by strong male guardians ... preaching obedience and the regulation of a little girl's sexuality' (Zipes 1993, p.66). Furthermore Zipes argues that 'all [the] traditional heroines of "Little Red Riding Hood" stories ... [are] responsible for ... [their] own downfall and for the rapaciousness of wolflike creatures ... a self-induced rape and murder' (p.49). Thus, while the tale warns of the physical dangers posed by a wolf/stranger, it also emphasises the need to regulate the (female) appetite for pleasure, and most significantly it blames the victim for her fate.

'Little Red Riding Hood' is probably one of the best known traditional fairy tales and it continues to be influential and to spawn new translations. While the trouble caused by the transgressive behaviour of young girls is implicit in 'Little Red Riding Hood' it is still the cannibalistic wolf/stranger who is the explicit enemy in the story. In Angela Carter's translation of Perrault's version the moral of the story is made absolutely clear:

Children, especially pretty, nicely brought-up young ladies, ought never to talk to strangers; if they are foolish enough to do so, they should not be surprised if some greedy wolf consumes them, elegant red riding hoods and all.

Now there are real wolves, with hairy pelts and enormous teeth; but also wolves who seem perfectly charming, sweet-natured and obliging, who pursue young girls in the street and pay them the most flattering attentions.

Unfortunately, these smooth-tongued, smoothpelted wolves are the most dangerous of all.

(1977, p.28)

Thus while real wolves were an actual danger in medieval times of famine, they have since become a metaphor for those who are, as Carter puts it, 'hairy on the inside' (1979, p.290). The threat of consumption/cannibalism they now exude is a metaphor for rape. The wolf has become a paedophile.

\section{Contemporary Wolf Tales}

C. S. Lewis's faun, Mr Tumnus, half-man, half-goat, has suspect intentions when he invites Lucy to his house for tea in The Lion, the Witch and the Wardrobe (1950). As a faun he can be identified with Pan, the goat-god in Greek mythology who was the god of pastures and wild places, extremely lustful and renowned for pursuing virginal nymphs (Philip 1999, pp.42-43). Lucy's response to $\mathrm{Mr}$ Tumnus's invitation is polite but she initially expresses reservations: 'Thank you very much, Mr Tumnus ... But I was wondering whether I ought to be getting back'. The faun is persuasive, however, swaying her with promises of food: 'It's only just round the corner ... and there'll be a roaring fire - and toast — and sardines — and cake' ${ }^{4}$ Lucy is won over and soon 'found herself walking through the wood arm in arm with this strange creature' (Lewis 1990/1950, pp.17-19). Mervyn Nicholson claims that metaphorically, in inviting Lucy to tea, Mr Tumnus is attempting to seduce 
her. He points out that the appearance of food and drink is a natural appetiser to seduction (1992, p.55).

Mr Tumnus's book collection reveals his interests: 'They had titles like The Life and Letters of Silenus or Nymphs and Their Ways' (Lewis, p.19). In Greek myth Silenus was a drunken satyr, constant companion and tutor to Dionysus (Bacchus) and leader of his revellers. Satyrs were spirits with goat-like characteristics not least of which was their uninhibited lust (Philip 1999, p.41, p.58). While nymphs were, in mythology, spirits of nature represented as beautiful young women, the word nymph is also the root of nymphet, a girl who is sexually precocious and desirable, and of nymphomaniac. Some of the titles in Mr Tumnus's library clearly have sexual overtones.

Mr Tumnus is 'in the pay of the White Witch' (Lewis, p.23) and has been commissioned to capture for her any 'Son of Adam or ... Daughter of Eve' he might meet in the woods. He confesses that he has 'pretended to be [Lucy's] friend and asked [her] to tea, and all the time [he's] been meaning to wait till [she was] asleep and then go and tell Her"'(p.24, original emphasis). But, the tea Mr Tumnus provides for Lucy is coded as unequivocally wholesome. Nicholson argues that the wholesome quality of the food indicates that for Lewis the male version of the seduction story is invalid. 'Males do not, so to speak, illegitimately prey on females' (1992, p.55). I take this to mean that preying by males on females is regarded as legitimate and that it is women (and Nicholson cites as an example the White Witch seducing Edmund with the turkish delight) who illegitimately prey on men and seduce them with food. Food, Nicholson argues, is only effectual as a tool of seduction when employed by the female figure as bait (1992,p.57).

Margaret Mahy's book, The Changeover (1984), captures the menace of the sexual predator who targets children. This is a modern fairy tale containing many traditional elements: there are witches, a stepmother, a budding romance and a monster that consumes innocent children. Carmody Braque is an ancient supernatural spirit who survives by absorbing the vitality of humans. Laura is looking after her three-year old brother Jacko and the little boy entrances Braque:

'Oh...' he cried when he saw Jacko, 'a baby!' He put a very heavy, bleating emphasis on the first half of the word. 'A baaaab-y!' he exclaimed again in a high-pitched voice, breathing out as he bleated ... breathing in at the very end so that the word was finally sucked away to nothing.

(1995/1984, p.20)

Braque is like a wolf in sheep's clothing. His teeth are 'too big for his thin, rubbery lips to cover them ... his whole face was somehow shrunken back around his smile ... He was almost completely bald ... and there were dark blotches on his cheeks and neck, almost, but not quite like bruises' (p.20). The man has 'another discoloured blotch' on his hand 'as if he were starting to go bad' (p.21). Notions of disease and decay are conjured up by Braque's appearance and this is reiterated by the 'dreadful smell' that emanates from him and strikes Laura 'like a blow — a smell that brought to mind mildew, wet mattresses, unopened rooms, stale sweat, dreary books full of damp pages and pathetic misinformation, the very smell ... of rotting time' (pp.2021). Abjection and disgust are thus evoked.

Braque thinks Jacko is 'absolutely scrumptious', that is, edible, and, even though Laura hasn't bought anything in his shop, he offers to give Jacko a little ink stamp on his hand to match the Mickey Mouse one he'd got earlier from the librarian. With 'fearsome generosity' Braque cries,

'I'll make it up to the little brother, poor, wee lambie. Do I see a stamp on the right paw? How about another on the left? Hold it out, you little tiger, tiger burning bright, and you shall enter the forests of the night'.

(pp.21-22)

Braque pounces like 'an elderly mantis on an innocent fly', pressing the stamp onto the back of Jacko's hand. The stamp 'was the very face of Carmody Braque himself' and 'seemed to be under his skin, not on top of it' (p.23, original emphasis). There is no mistaking the animalistic consuming nature of this particular monster. Laura tries to wash the 'mark' off when they get home 'but the stamp was part of him now, more than a tattoo - a sort of parasite picture tunnelling its way deeper and deeper, feeding itself as it went' (p.31). Braque is a 'lemure', 'a wicked spirit that has managed to win a body for itself'. He parasitically 
absorbs the life energy of his victims in order to sustain his human form. The stamp is Braque's 'mark', a conduit connecting him to Jacko, which enables him to consume the child's 'essence' (p.82). The implicit sexuality of Braque's appetite becomes clear when he confesses to Laura that he's 'something of a gourmet':

'I've fed on so many by now I'm very very choosy. Girls like you, with rather more vitality perhaps, or sleeker, or those younger still - eight is an attractive age I think, ten is almost too old ... I enjoy an innocent, sucking baby ... Oh, the delectable banquet of possibility all you people offer me!' (pp.162-3)

Mahy's story concerns not only Laura's 'changeover' from child to adult but also her supernatural initiation into witchcraft. Becoming a witch and placing her own mark on Braque is the only way she can save Jacko. She and Sorensen, known as Sorry, a young male witch who is sexually attracted to her, work out a plan. She must persuade Braque to accept her as a victim in exchange for relinquishing his hold on Jacko. Sorry and Laura discuss the way she should present herself to Braque in order to tempt him:

\section{'We'll tempt him with variety', Sorry said, 'with the prospect of a willing sacrifice. Can you manage to look alluring and yet act as if you were constantly shrinking away from the thought of him'}

'Shall I try to look slinky?' Laura asked. (p.158)

Sorry tells Laura she's 'too young for slinky'. She's 'Young and knobbly — you know, like a foal! But you're a bit of a mixture, for all that, and that's what just might get him'. Laura asks him what he means by 'a mixture'. 'You know!' he said. 'At first you look skinny, but you're quite voluptuous in your way. If anyone thinks about you, that is!' (pp.158-159). While there is clearly sexual tension between Sorry and Laura, her appeal to Braque must be sexualised because he is recognised as a sexual predator attracted to children. Braque's desire focuses on the young, innocent and vulnerable, his 'mark' penetrates the body and he parasitically feeds on his victims. The insidious consuming nature of this monster is clearly pederastic.

In a similar way Maurice Gee's The Fat Man (1994) features an adult who implicitly exudes sexual menace. Colin Potter is a hungry child, skinny and greedy as well (1994, p.9). He steals a bar of chocolate belonging to the fat man, Herbert Muskie. Significantly, immediately prior to this theft Colin had spied upon Muskie taking a bath in a creek. Much emphasis is placed upon the description of Muskie's body.

[He is] white with soapsuds. They were pasted down his arms and across his shoulders. Froth blossomed in his armpits and stood like whipped cream on top of his head. He soaped his belly and tried to reach his back... He soaped all the creases in his fat and scraped the suds out with his fingernails.

Colin lay under the ferns and watched. He saw the man's behind gleaming like an eel's belly in the water. He saw him roll and submerge and come up with his head as smooth as an egg and the black hair on his chestpasted down like slime. Hesquirted creek water from his mouth like a draughthorse peeing and washed around his ears and dug in them, wiggling his finger ... [He] swam on his back to the deep part of the pool, where he rolled over like a whale. He was good in the water ... he smeared [handfuls of creek mud] on his belly and laughed. He could float so well, Colin thought, because he was so fat.

(pp.11-12)

Muskie, wearing only his underpants, discovers Colin eating his chocolate and grabs him 'with the strength of a possum trap' and threatens to 'belt him' (p.14). He stands over the boy with 'his bare sole on Colin's ankle' (p.15). Colin has 'never seen anyone as terrifying' as Muskie. He is 'round and fat ... pink and white and quivering'. His chest is 'folded' and he has 'creased sides and [a] blown-up belly ... His eyes were angry. They were small and deep and blacker than sheep pellets'. 'Muskie was like something that had rushed into the daylight from the back of a cave and was looking at what it had caught. For a moment Colin believed he was going to be killed' (p.14).

Muskie's body and his animality are emphasised. He not only squirts water from his mouth 'like a draughthorse 
peeing', rolls in the water like a whale, and has a 'behind' that gleams 'like an eel's belly', he also has eyes likened to 'sheep pellets'. Muskie's alignment with the bestial evokes disgust because disgust results from 'a psychic need to avoid reminders of our animal origins' (Miller 1998, p.6). Abjection and disgust are also evoked by the emphasis on body fluids and slime: soapsuds are pasted down the man's arms, his behind gleams like an eel (popularly considered to be slimy creatures), and his chest hair is 'pasted down like slime'. The author's use of horse urine as a simile for the way water is squirted from Muskie's mouth, and sheep pellets as a comparison for the blackness of his eyes is also significant.

Considerable emphasis is placed upon the alien hugeness of the man's body, seen through the eyes of a skinny, hungry child. There is something disgusting about the contorted fleshiness of his obesity. Probyn speculates that it is the idea of all the food that went into the making of an obese body that makes it disgusting; the rolls of fat show 'the visible evidence of ... contamination by what they have ingested' (2000, p.130). She cites Claude Fischler who argues that the obese make society queasy because they remind us of the finitude of food; 'the consequence is clear: whoever consumes more than their fair share, deprives others of theirs' (in Probyn 2000, p.130). If this is the case then the comparison of Muskie, who's had more than his fair share, with Colin, who has been deprived, is unavoidable.

Both Colin and the reader 'view' the man bathing, a ritual normally performed in private and, indeed, Muskie presumes he is alone. Protagonist and reader are consequently cast in the role of voyeurs. Muskie's obvious sensuous enjoyment of both the water and the process of cleaning his body together with the implicit 'peeping Tom' position assigned to the viewing children (Colin and reader) introduces a sexual imperative into the narrative. While it evokes horror and disgust, the description of Muskie's body also, therefore, holds a level of fascination. Disgust, as Miller points out, 'can attract as well as repel; the film and entertainment industries, among which we might include news coverage, literally bank on its allure' (1998, p.x). Julia Kristeva, too, argues that disgusting things involve us in 'a vortex of summons and repulsion' (1982, p.1) and similarly the related abject 'simultaneously beseeches and pulverizes the subject' (p.5). The description of Muskie's body is both disgusting and curiously alluring. Part of the fascination for the hungry, skinny child arguably lies in the fact that, inherent in the obese body, is the reality of the vast quantities of rich food required to produce it - food which the child must inevitably covet.

Muskie drops 'a gob of spit' (Gee 1994, p.15) onto the chocolate bar and, quoting the old adage 'waste not, want not', he forces Colin to 'open up' (p.14) and eat it. He threatens the boy with a razor until he complies. Muskie's near nakedness and his size and strength relative to the 'skinny' powerless child coupled with their relative proximity (Colin's head is presumably level with Muskie's groin) make this scene particularly horrific. The ingestion of the 'gob of spit' violates deeply held norms about the polluting, contaminating nature of body fluids that have already been called to mind by the description of the man's body. The forced penetration of the child's mouth/body by the spit-covered chocolate leads me to interpret this event as oral rape.

Mahy's and Gee's narratives in particular warn of but also invoke stranger danger. The monster looks human (specifically like a man). As with most monsters he has an uncontrolled appetite for the 'wrong' thing. He desires to consume children, to use his adult power to corrupt the 'innocence' of childhood and to violently annihilate. He is the child abuser, the paedophile.

As I commented at the beginning of this paper it is the inhumanity of the consuming monster that we fear. As Probyn argues, "the cannibal reminds us of that which cannot be included in the polis, the social life of man. Yet its very exclusion serves to define humanity'. The cannibal 'is to be understood as the ground zero of humanity, the very limits of being human' (2000, p.88). Contemporary fears about paedophiles make them representative of the 'ground zero of humanity' and child abuse one of the defining moments when man becomes inhuman. As Warner argues, 'child-snatchers, child-killers, sexual violators of the young horrify us at some deeper, personal level than even the atrocities of recent civil wars' (2000, p.385). Fictional monsters embody cultural fears of such inhumanity towards those we value and most fear to lose. Warner in fact believes that 'paedophiles are our late millennial ogres' (p.386). 
Tales of abominable monsters that threaten to consume may warn of material dangers, as was the case with the early oral folk tale versions of many of today's favourite fairy tales. Stories, lullabies and playground games that feature hungry wolves and monsters rehearse the fears invoked by the threat these monsters represent, the fear of being literally eaten or annihilated through metaphorical consumption such as child abuse and rape. They may thus have a therapeutic function. Stories like 'The Juniper Tree', explore issues regarding intergenerational and familial rivalries, confirming the individual's place in society, or they may, like 'Little Red Riding Hood' be designed to reflect society's concerns about the need to discipline the appetites and behaviour of children. Above all monster stories mirror social unease about enemy 'Others', whose identity changes over time. Pederastic monsters such as Mahy's Carmody Braque and Gee's Herbert Muskie represent, for contemporary culture, the epitome of monstrousness. They have human faces but they are, to reiterate Angela Carter's phrase, 'hairy on the inside'.

\section{ENDNOTES}

1. In 2001 the German 'cannibal', identified as Armin M., advertised on the Internet for a 'young, well-built' man to slaughter. He apparently carved up and froze portions of his victim's flesh and later ate some of it (http://news.bbc.co.uk/2/hi/europe/3075897.stm accessed 9/12/03).

2. In her novel (for adults) Alias Grace, Margaret Atwood uses the same notion to good effect. The novel is set initially in mid-nineteenth century Ireland. Grace's family is poor, her father is an alcoholic and there are already seven children in the family. While they are not starving, food is scarce. Grace recalls that when yet another baby arrives,

our father said we should just knock the new baby on the head and shove it into a hole in the cabbage patch, as it would be a good deal happier under the sod than above it. And then he said it made him hungry just to look at it, it would look very nice on a platter with roast potatoes all round and an apple in its mouth. And then he said why were we all staring at him.

(1996, p.10)

3. All these tales appear in Jack Zipes' collection: The Complete Fairy Tales of the Brothers Grimm (1992/1987).

4. Lewis's book was published during a period of postwar rationing when the majority of people in England were eating less than they had throughout the whole of the twentieth century. Food rationing began in January 1940 and continued until 1954 (Barker 1982, p. 9). In this context Mr Tumnus's offer of cake in particular must be read as very tempting.

5. The following excerpt from an article in Marie Claire magazine reveals the unmistakable similarities between Braque's desires and those of 'Steve, 51', a 'situational child abuser' (men on holiday who 'experiment' with children). Steve prefers 'Young ones ... They're soft, they'll do anything and they don't complain. I like ones with no hair. They're like babies, little dolls'. He says 'I'd be damned if I'd take even a fifteen year old girl now'. Significantly he adds 'If you like young meat, you've got to go to Cambodia' (Frederick 1999, p.54, emphasis added). The semantic links between paedophilia and cannibalism are clear.

6. Arguably the sense in which Muskie's bulk literally embodies the rich, fattening foods which have produced it is emphasised by the way his body is garnished by froth which 'stood like whipped cream on top of his head' (Gee 1994, p.11). 


\section{REFERENCES}

Atwood, Margaret (1997) Alias Grace. London, Virago.

Bakhtin, Mikhail (1984/1965) Rabelais and His World. Trans. H. Iswolsky. Bloomington, Indiana University Press.

Ballantyne, R. [n.d./1858] The Coral Island. London, Thames.

Bradford, Clare (2001) Reading Race: Aboriginality in Australian Children's Literature. Carlton South, Victoria, Melbourne University Press.

Carter, Angela (1977) The Fairy Tales of Charles Perrault. London, Gollancz.

Carter, Angela (1979) 'The Company of Wolves' in Jack Zipes (1993) The Trials and Tribulations of Little Red Riding Hood. New York, Routledge, pp.282-291.

Devereaux, George (1966) 'The cannibalistic impulses of parents' in Basic Problems of Ethnopsychiatry, (1980) Chicago, University of Chicago Press, pp.122-137.

Dundes, Alan (1988) 'Interpreting "Little Red Riding Hood" psychoanalytically' in James McGlathery (ed) The Brothers Grimm and Folktale. Chicago, University of Illinois Press, pp.16-51.

Freud, Sigmund (1925) 'Negation' in Peter Gay (ed) (1989) The Freud Reader. New York, Norton, pp. 666-669.

Freud, Sigmund (1912-13) 'Totem and Taboo' in Peter Gay (ed) (1989) The Freud Reader. New York, Norton, pp. 481-513.

Gee, Maurice (1994) The Fat Man. Ringwood Victoria, Penguin.

Kilgour, Maggie (1990) From Communion to Cannibalism: An Anatomy of Metaphors of Incorporation. New Jersey, Princeton University Press.
Kilgour, Maggie (1998) 'The function of cannibalism at the present time' in F. Barker, P. Hulme \& M. Iverson (eds) Cannibalism and the Colonial World. Cambridge, Cambridge University Press, pp. 238-259.

Klein, Melanie (1981) Love, Guilt and Reparation: And Other Works 1921-1945. London, Hogarth Press.

Kristeva, Julia (1982) Powers of Horror: An Essay on Abjection. Trans. Leon S. Roudiez. New York, Columbia University Press.

Lévi-Strauss, Claude (1966) 'The culinary triangle' in Partisan Review 33: 586-95.

Lewis, C. S. (1990) [1950] The Lion, the Witch and the Wardrobe. London, Collins.

Mahy, Margaret (1995) [1984] The Changeover. Ringwood, Penguin.

McGlathery, James (ed) (1988) The Brothers Grimm and Folktale. Chicago, University of Illinois Press.

Miller, William (1998) The Anatomy of Disgust. Cambridge, Harvard University Press.

Nicholson, Mervyn (1992) 'Magic food, compulsive eating, and power poetics' in Lilian Furst and Peter Graham (eds) Disorderly Eaters: Texts in Self-Empowerment. University Park, PA, Pennsylvania State University Press, pp. 43-60.

Obeyesekeve, Gananath (1998) 'Cannibal feasts in nineteenth-century Fiji: seaman's yarns and the ethnographic imagination' in F. Barker, P. Hulme \& M. Iverson (eds) Cannibalism and the Colonial World. Cambridge, Cambridge University Press, pp. 63-86.

Philip, Neil (1999) Myths \& Legends. London, Dorling Kindersley.

Probyn, Elspeth (2000) Carnal Appetites: FoodSexIdentities. London, Routledge.

Pullman, Philip (1995) Northern Lights. London, Scholastic. 
Pullman, Philip (2001) The Amber Spyglass. London, Scholastic.

Rowe, Richard (1869) The Boy in the Bush. London, Bell \& Daldy.

Sceats, Sarah (2000) Food, Consumption and the Body in Contemporary Women's Fiction. Cambridge, Cambridge University Press.

Seabrook, William (1993) 'Cannibals' in C. Spencer \& C. Clifton (eds) The Faber Book of Food. London, Faber and Faber, pp.536-540.

Skubal, Susanne (2002) Word of Mouth: Food and Fiction after Freud. London, Routledge.

Tatar, Maria (1992) Off With Their Heads! Fairy Tales and the Culture of Childhood. Princeton, Princeton University Press.

Turner, Ian, June Factor and Wendy Lowenstein (1978) Cinderella Dressed in Yella. Richmond Victoria, Heinemann Educational.

Visser, Margaret (1993) The Rituals of Dinner: The Origins, Evolution, Eccentricities, and Meaning of Table Manners. London, Penguin.

Warner, Marina (2000) No Go the Bogeyman: Scaring, Lulling and Making Mock. London, Vintage.

Wignell, Edel (1990) A Bogy Will Get You! Marrickville, Harcourt, Brace, Jovanovich.
Willard, Tracy (2002a) (accessed 25/10/2002) 'Little Red Riding Hood: Cannibal mothers' in Tales at the Borders: Fairy Tales and Maternal Cannibalism. http://www. reconstruction.ws/022/cannibal/littlered.html

Willard, Tracy, (2002b) (accessed 25/10/2002) 'Snow White, Sleeping Beauty, The Juniper Tree, The Virgin Mary's Child: The wicked cannibal queen' in Tales at the Borders: Fairy Tales and Maternal Cannibalism, http://www. reconstruction.ws/022/cannibal/snowwhite. html

Zipes, Jack (1992) [1987] The Complete Fairy Tales of the Brothers Grimm. New York, Bantam Books.

Zipes, Jack (1993) The Trials and Tribulations of Little Red Riding Hood. New York, Routledge.

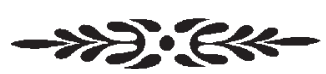

\section{BIOGRAPHICAL NOTE}

Carolyn Daniel and her family moved from the UK to Australia ten years ago. She began her undergraduate career in 1997 as a mature age student at Victoria University and has been studying full-time for seven years. Now at Monash, Carolyn is working on her $\mathrm{PhD}$ thesis provisionally titled 'Tasting the World: Food, Orality and Embodiment in Children's Literature'. 